\title{
MOTIVASI PETANI, FAKTOR PENDORONG DAN FAKTOR PENGHAMBAT DALAM BUDIDAYA TANAMAN CENGKEH DI MUKIM LAMPUUK KECAMATAN LHOKNGA KABUPATEN ACEH BESAR
}

\author{
(Motivation Of Farmers, Power Factors And Drug Factors In Plant Cultivation In Mukim \\ Lampuuk District Lhoknga District Aceh Big District)
}

\author{
Muhammad Sofwan ${ }^{\mathbf{1}}$, Ahmad Humam Hamid ${ }^{1}$, Irwan A Kadir ${ }^{\text {* }}$ \\ ${ }^{1}$ Program Studi Agribisnis, Fakultas Pertanian, Universitas Syiah Kuala
}

\begin{abstract}
Abstrak Cengkeh memiliki peranan yang cukup besar dalam pembangunan di bidang perekonomian di Indonesia. Perkembangan produksi dan harga cengkeh di Indonesia dari tahun 2003 - sekarang berfluktuasi dengan kecendrungan meningkat setiap tahunnya dengan rata-rata tingkat pertumbuhan sebesar 1\%. Namun permasalahan harga merupakan masalah utama dalam budidaya tanaman cengkeh. Penelitian ini bertujuan untuk melihat seberapa besar tingkat motivasi petani, terhadap budidaya tanaman cengkeh dan melihat hubungan antara Faktor pendorong motivasi petani dengan tingkat motivasi petani, dan factor penghambat motivasi petani dengan tingkat motivasi petani di Mukim Lampuuk Kecamatan Lhoknga. Penelitian menggunakan metode survey, data dikumpulkan dari wawancara dengan petani responden yang diambil dengan cara cluster sampling dan sample proposional . Total responden dalam penelitian ini sebanyak 50 responden. Analisis data menunjukkan bahwa motivasi petani cengkeh berada pada kategori tinggi, yaitu 52\%. Petani menanam tanaman cengkeh dapat memenuhi kebutuhan ekonominya dan membawa dampak positif secara sosial. Hubungan antara faktor pendorong dengan motivasi petani dengan nilai signifikan 0,01 dan berhubungan searah. Sedangkan faktor pendorong: lingkungan ekonomi dan status sosial ekonomi berpengaruh nyata. dan faktor penghambat dengan motivasi petani tidak berpengaruh nyata, didalamnya antara lain; hama dan penyakit serta ketidaktersediannya kredit usaha tani.
\end{abstract}

Kata kunci : Perkembangan cengkeh, permalasahan, motivasi petani, factor pendorong,factor penghambat.

\begin{abstract}
Cloves have a considerable role in the development in the field of economy in Indonesia. Development of production and the price of cloves in Indonesia from the year 2003 - present fluctuating trend is increasing every year, with an average growth rate of $1 \%$. But the main issue is the price problems in the cultivation of cloves. This research aims to look at how big the level of motivation of farmers, against the cultivated crops of clove and see the relationships between the Factors driving the motivation of farmers with a level of motivation of farmers, and the factor restricting farmer motivation with a the level of motivation of farmers in Lhoknga Subdistrict Mukim Lampuuk. Research using survey method, data were collected from interviews with farmers respondents were taken by means of cluster sampling and sample proportional. Total respondents in this study as many as 50 respondents. Data analysis showed that the motivation of clove farmers are on a high category, i.e. 52\%. Farmers plant crops of clove can meet the needs of the economy and bring positive impact socially. The relationship between driving factor with the motivation of farmers with a significant value of 0.01 and connect direct. While the driving factor: economic environment and socio-economic status effect is real. restricting factors and with the motivation of farmers do not affect real, therein, among others; pests and diseases as well as the unavailability of farming credit.
\end{abstract}

Keywords: Development of cloves, problems, motivation of farmers, driving factors, inhibiting factors.

\section{PENDAHULUAN}

Cengkeh merupakan tanaman tradisional yang sudah lama ada di Indonesia. Walaupun demikian, cengkeh memiliki peranan yang cukup besar dalam pembangunan di bidang perekonomian, terutama untuk mendukung pertumbuhan industri. Peranan pembangunan dibidang ekonomi salah satunya tercermin dari perkembangan perkebunan tanaman cengkeh. Perkembangan produksi dan harga cengkeh di Indonesia pada periode tahun 2003 - 2010 berfluktuasi dengan kecendrungan meningkat setiap tahunnya. Dampak dari harga jual yang 
tidak menentu menyebabkan keengganan petani untuk tetap memelihara tanamannya sehingga tanaman menjadi rentan terhadap serangan hama dan penyakit. Permasalahan harga tersebut membuat pemerintah mengeluarkan kebijakan yang mengatur tata niaga cengkeh melalui pembentukan Badan Penyangga dan Pemasaran Cengkeh (BPPC).

Berdasarkan data biofisik yang dituangkan dalam peta pewilayahan komoditas, kabupaten Aceh Besar cukup potensial untuk pengembangan tanaman perkebunan. Dengan didukung oleh data luas tanam/luas panen, dan produksi/produktivitas analisa usahatani dan kebijakan pemerintah daerah, maka tanaman perkebunan cengkeh merupakan salah satu komoditas andalan untuk Kabupaten Aceh Besar. Salah satu daerah sentral produksi cengkeh di Kabupaten Aceh Besar adalah Kecamatan Lhoknga. Kecamatan Lhoknga menjadi penghasil terbanyak dari 684 ton, Kecamatan Lhoknga menyumbang 153,5 ton untuk produksi Cengkeh Aceh Besar atau sebesar 22,44\%.

Pada periode 1960an, Kecamatan Lhoknga mengalami masa gemilang sebagai penghasil cengkeh. Ketika cengkeh mendapat pasaran yang baik dalam sektor perdagangan, maka masyarakat Lhoknga berusaha untuk menanam dan memperluas ladang-ladang cengkeh mereka. Pada tahun 1960an harga cengkeh sangat mahal, satu kilogram setara satu gram emas. Karena harga cengkeh yang tinggi maka banyak masyarakat Lhoknga dan luar Lhoknga ikut menanam cengkeh, bahkan semua pemilik kebun dapat mengumpulkan uang untuk naik haji, membangun rumah, termasuk menghidupi sejumlah pekerja (Dahlan Ketua Kel. Tani, 2017). Namun berbagai permasalahan muncul seiring dengan berbagai kepentingan dan kondisi perubahan sumber daya alam. Salah satunya yaitu ketidakstabilan harga petani cengkeh.

Pasang surut kehidupan petani cengkeh juga terjadi dalam struktur sosial ekonomi petani cengkeh di Lhoknga. Beragam masalah yang muncul pada petani cengkeh adalah berdasarkan cerita masyarakat setempat mulai dari yang dulunya seluruh tanaman cengkeh mengalami masa penyusutan akibat serangan hama penyakit, GAM di Aceh sampai musibah tsunami yang pernah terjadi di Aceh, sehingga banyak masyarakat Lhoknga yang dulunya bekerja sebagai petani cengkeh tidak memiliki mata pencaharian lagi, sehingga mayoritas petani dari mereka meniggalkan usaha cengkeh dan mencari pekerjaan di luar Lhoknga. Dan Permasalahan besar yang dialami petani cengkeh adalah fluktuasi harga terhadap turunnya kembali harga cengkeh yang sudah terlanjur mereka garap.

Dewasa ini petani mulai menanami cengkeh yang dulunya pernah ditinggal dan membudidayakannya kembali, juga upaya petani yang tetap bertahan dengan pertanian cengkeh mengindikasikan adanya hal yang menjadi alasan bagi petani itu, alasan yang tidak dimiliki oleh petani lainnya. Alasan yang dimaksud seperti adanya hubungan yang dimiliki oleh petani dengan pihak luar, pihak yang mampu memberikan informasi kepada petani untuk tetap bertahan, atau bahkan pihak yang mampu menjamin untuk dapat menampung hasil produksi dari petani. Adapun tujuan dalam penelitian ini adalah; 1. Mengetahui tingkat motivasi petani dalam budidaya tanaman cangkeh, 2. Mengetahui hubungan tingkat Faktorfaktor yang mendorong motivasi petani dengat tingkat motivasi petani, dan 3. Mengetahui hubungan tingkat Faktor-faktor yang menghambat motivasi petani dengat tingkat motivasi petani dalam budidaya tanaman cangkeh.

\section{METODE PENELITIAN}

Penelitian ini dilakukan di Mukim Lampuuk Kecamatan Lhoknga Kabupaten Aceh Besar. Pemilihan lokasi penelitian dilakukan secara purposive yaitu dengan sengaja karena mempertimbangkan bahwa Kecamatan Lhoknga merupakan daerah produksi penghasil cengkeh terbanyak di Kabupaten Aceh Besar. Objek dari penelitian ini adalah petani cengkeh sedangkan ruang lingkup dalam penelitian ini adalah motivasi, faktor pendorong dan faktor penghambat petani yang 
membudidayakan tanaman cengkeh di Mukim Lampuuk Kecamatan Lhoknga Kabupaten Aceh Besar. Populasi dalam penelitian ini adalah semua Petani yang membudidayakan tanaman cengkeh di Mukim Lampuuk yang merupakan daerah terkonsentrasinya penghasil cengkeh.

Jumlah sampel dalam penelitian ini adalah responden yang tinggal menetap di Mukim Lampuuk Kecamatan Lhoknga yang telah ditentukan dengan menggunakan rumus Slovin dengan batas toleransi kesalahan sebesar 10\% dan didapat 50 sampel.

\section{Prosedur Pengujian Data}

Penelitian ini menggunakan Skala Likert untuk mengukur skor variabel Motivaasi petani yang dikategorikan menjadi tiga kategori besar yaitu rendah, sedang, dan tinggi (Sudjana, 2005). Hasil dari data yang di dapat kemudian diuji validitas dan reabilitasnya menggunakan aplikasi SPSS 16.0.

\section{Analisa Statistik}

Analisa statistik yang digunakan adalah analisis statistic descriptive dan Rank Spearman, yaitu dengan menyajikannya dalam bentuk tabel. untuk mencari tingkat motivasi petani dan mencari keeratan hubungan antara dua variabel yaitu factor pendorong, dan factor penghambat dengan motivaasi petaani cengkeh. Dalam menentukan tingkat kekuatan hubungan antar variabel, kita dapat berpedoman pada nilai koefisien korelasi yang merupakan hasil dari output SPSS 16.0.

\section{Motivasi Petani dalam Budidaya Tanaman Cengkeh}

\section{HASIL DAN PEMBAHASAN}

Setiap petani mempunyai motivasi yang berbeda sebagai pendorong dalam melakukan suatu usahatani. Motivasi petani diartikan sebagai suatu kondisi yang mendorong seseorang untuk melaksanakan suatu tindakan dalam rangka mencapai tujuannya. Motivasi dalam penelitian ini terdiri dari motivasi ekonomi dan motivasi sosiologis.

\section{a. Motivasi Ekonomi (Y1)}

Motivasi ekonomi yaitu kondisi yang mendorong petani untuk memenuhi kebutuhan ekonomi. Pengukuran motivasi ekonomi dilakukan dengan empat indikator yaitu keinginan untuk memenuhi kebutuhan hidup keluarga, keinginan untuk memperoleh pendapatan yang lebih tinggi, keinginan untuk memiliki dan meningkatkan tabungan, dan keinginan untuk hidup lebih sejahtera atau hidup lebih baik.

Tabel 1. Kategori Tingkat Motivasi Ekonomi Responden di Mukim Lampuk

\begin{tabular}{cccc}
\hline Tingkat Motivasi & Kategori & Frekuensi Sampel & persentase (\%) \\
\hline $\mathbf{1 8 - 2 0}$ & Rendah & 12 & $24 \%$ \\
$\mathbf{2 1 - 2 2}$ & Sedang & 14 & $28 \%$ \\
$\mathbf{2 3 - 2 5}$ & Tinggi & 24 & $48 \%$ \\
\hline Jumlah & & 50 & $100 \%$ \\
\hline
\end{tabular}

Sumber: Data Primer(Diolah), 2017

Berdasarkan Pada Tabel 1 dapat dilihat bahwa bahwa tingkat motivasi ekonomi mayoritas responden berada pada kategori tinggi (48\%). Artinya bahwa responden petani yang menanam tanaman cengkeh dengan harapan yang tinggi dapat memenuhi kebutuhan ekonominya. Mata pencaharian pokok responden umumnya adalah sebagai petani bukan hanya sebagai petani cengkeh saja, tetapi merangkap sebagai petani padi dan juga jenis tanaman lainnya yang dapat ditanam pada lahan cengkeh mereka. Tujuan utama budidaya tanaman cengkeh yang dilakukan responden adalah untuk memenuhi kebutuhan ekonominya termasuk keinginannya dalam memenuhi kebutuhan hidup keluarga, keinginan untuk memiliki dan meningkatkan tabungan, keinginan untuk memperoleh pendapatan yang lebih tinggi, serta keinginan untuk hidup lebih sejahtera atau hidup lebih baik. 
Berdasarkan fakta keterangan dari lapangan, responden berharap agar harga cengkeh segera naik dan stabil. Harga yang ada pada saat sekarang ini sangat fluktuatif akan tetapi telah dapat mencukupi dan memenuhi kebutuhan hidup sehari-hari meski pendapatan responden termasuk dalam kategori rendah. Akan tetapi petani mempunyai harapan yang besar dengan tanaman cengkeh mereka. Dimana dengan pendapatan yang didapat pada saat ini, mereka mempunyai keinginan untuk memperoleh pendapatan yang lebih tinggi, keinginan untuk meningkatkan tabungan, serta keinginan untuk hidup lebih baik dari sebelumnya yang belum bisa tercapai. Motivasi ekonomi menanam tanaman cengkeh memang tinggi karena harapan mereka untuk dapat memenuhi kebutuhan ekonomi sangat besar.

\section{b. Motivasi Sosiologis (Y2)}

Motivasi sosiologis yaitu kondisi yang mendorong petani untuk memenuhi kebutuhan sosial dan berinteraksi dengan orang lain karena petani hidup bermasyarakat. Pengukuran motivasi sosiologis dilakukan dengan lima indikator yaitu keinginan untuk menambah relasi atau teman, keinginan untuk bekerjasama dengan orang lain, keinginan untuk mempererat kerukunan, keinginan untuk dapat bertukar pendapat, dan keinginan untuk dapat memperoleh bantuan dari pihak lain.

Tabel 2. Kategori Tingkat Motivasi Sosiologis Responden di Mukim Lampuk

\begin{tabular}{cccc}
\hline Tingkat Motivasi & Kategori & Frekuensi Sampel & persentase (\%) \\
\hline $\mathbf{1 6 - 1 8}$ & Rendah & 14 & $28 \%$ \\
$\mathbf{1 9 - 2 0}$ & Sedang & 15 & $30 \%$ \\
$\mathbf{2 1 - 2 3}$ & Tinggi & 21 & $42 \%$ \\
\hline Jumlah & & 50 & $100 \%$ \\
\hline
\end{tabular}

Sumber : Data Primer (Diolah), 2017

Pada Tabel 2 dapat diketahui bahwa tingkat motivasi ekonomi mayoritas responden berada pada kategori tinggi (42\%). Artinya bahwa responden beranggapan bahwa menanam tanaman cengkeh dapat membawa dampak positif secara sosial yaitu dapat mempererat persaudaraan antar petani sehingga terjalin kerjasama yang baik. Adanya kerjasama yang baik tersebut maka responden dapat bertukar pengalaman dan informasi, terutama informasi yang bermanfaat untuk peningkatan usahatani mereka.

Terkait dengan keinginan untuk menambah relasi atau teman, keinginan untuk bekerjasama dengan orang lain, keinginan untuk mempererat kerukunan, keinginan untuk dapat bertukar pendapat, dan keinginan untuk dapat memperoleh bantuan dari pihak lain, hal ini bisa muncul meskipun petani tidak membudidayakan tanaman cengkeh. Keinginan itu pasti ada tetapi dengan budidaya tanaman cengkeh, petani semakin mempunyai hubungan sosial yang lebih dekat. Misalnya, setelah budidaya tanaman cengkeh terbentuklah kelompok tani tanaman cengkeh. Adanya kelompok tani ini menjadi wadah mereka untuk bertukar pendapat, menjaga kerukunan, bekerjasama dengan orang lain serta memperoleh bantuan dari pihak lain.

Kehidupan bermasyarakat memang mengharuskan petani untuk membangun hubungan dengan orang lain. Manusia sebagai makhluk sosial tidak bisa hidup sendiri karena dalam kehidupan, pastinya membutuhkan orang lain. Adanya motivasi sosiologis yang tinggi pada responden ini juga menunjukkan bahwa petani dapat bergabung dengan orang lain, dapat bekerjasama, serta bertukar informasi. Kehidupan masyarakat di desa juga masih sangat erat, sehingga rasa sosial responden juga tinggi

\section{Motivasi Petani dalam Budidaya Tanaman Cengkeh (Y Total)}

Motivasi seseorang timbul karena adanya kekurangan akan suatu kebutuhan yang diinginkan. Hal tersebut menyebabkan seseorang bertindak atau berusaha untuk memenuhi 
kebutuhannya.Dapat dikatakan juga bahwa motivasi ada karena adanya tujuan dan kebutuhan tertentu seseorang. Hal ini juga terjadi pada diri respoden yang melakukan budidaya tanaman cengkeh, tentu mereka memiliki tujuan dan kebutuhan tertentu.

Tabel 3. Kategori Tingkat Motivasi Petani Responden di Mukim Lampuk

\begin{tabular}{cccc}
\hline Tingkat Motivasi & Kategori & Frekuensi & persentase $(\%)$ \\
\hline $\mathbf{3 5 - 3 8}$ & Rendah & 9 & $18 \%$ \\
$\mathbf{3 9 - 4 2}$ & Sedang & 15 & $30 \%$ \\
$\mathbf{4 3 - 4 7}$ & Tinggi & 26 & $52 \%$ \\
\hline Jumlah & & 50 & $100 \%$ \\
\hline
\end{tabular}

Sumber : Data Primer (Diolah), 2017

Berdasarkan Tabel 3 dapat diketahui motivasi petani dalam budidaya tanaman cengkeh berada pada kategori tinggi yaitu $52 \%$. Artinya bahwa responden membudidayakan tanaman cengkeh punya tujuan tertentu terkait dengan ekonomi dan sosialnya.Responden menanam tanaman cengkeh dengan harapan tinggi agar dapat memenuhi kebutuhan ekonominya serta beranggapan bahwa menanam tanaman cengkeh dapat membawa dampak positif secara sosial.Adanya motivasi yang tinggi ini perlu didukung peran pemerintah untuk membantu memulihkan kembali harga cengkeh sehingga petani memperoleh pendapatan lebih baik.

\section{Cengkeh}

Hubungan Motivasi Petani dengan Status Sosial Petani dalam Budidaya Tanaman

Analisis hubungan antara Status Sosial petani yang meliputi umur, pendidikan, luas lahan dan pendapatan dengan motivasi petani sangat penting diketahui untuk melihat sejauh mana hubungan antara variabel-variabel tersebut saling mempengaruhi. Untuk mengetahui hubungan antara umur, pendidikan, luas lahan dan pendapatandengan motivasi petani digunakan analisis korelasi Rank Spearman's dengan bantuan perangkat IBM SPSS (Statistical Package for Social Sciences) 24.

Tabel 4. Nilai Signifikan dan Koefiensi Korelasi Rank Spearman's Hubungan antara Umur, pendidikan, luas lahan dan pendapatan dengan motivasi petani

\begin{tabular}{lclcc}
\hline \multirow{2}{*}{$\begin{array}{l}\text { Status } \\
\text { Petani }\end{array}$} & \multicolumn{4}{c}{ Mosial } \\
\cline { 2 - 5 } & Sig. (2 tailed) & Kriteria & $\begin{array}{c}\text { Correlation } \\
\text { Coef. }\end{array}$ & Kriteria \\
\hline Umur & 0,355 & Tidak sig. & 0,134 & Sangat lemah \\
Pendidikan & 0,544 & Tidak sig. & 0,088 & Sangat lemah \\
Luas Lahan & 0,001 & Signifikan & $0,438^{* *}$ & Cukup \\
Pendapatan & 0,001 & Signifikan & $0,471^{* *}$ & Cukup \\
$\begin{array}{l}\text { Status Sosial } \\
\text { (total) }\end{array}$ & 0,004 & Signifikan & $0,401^{* *}$ & Cukup \\
\hline
\end{tabular}

Sumber: Data Primer (Diolah), $2017 \quad$ Keterangan: **) Berhubungan sangat nyata pada $\alpha=0,05$

Berdasar Tabel 4 diatas dapat dilihat bahwa hasil analisis menunjukkan hubungan yang signifikan dan hubungan yang tidak signifikan antar variabel. Untuk memahami makna angkaangka hasil analisis di atas dapat diuraikan sebagai berikut: 


\section{Hubungan antara umur dengan motivasi petani cengkeh}

Tingkat kekuatan (keeratan) hubungan antar variabel umur dan motivasi petani berdasarkan tabel output di atas maka dapat kita peroleh nilai koefisien korelasi sebesar 0,134. Bermakna untuk tingkat kekuatan hubungan antar variabelnya umur dengan motivasi petani dikatergorikan sangat lemah .

Melihat arah (jenis) hubungan antar variabel umur dengan motivasi petani pada angka koefisien korelasi pada tabel bernilai positif yaitu $(0,134)$, maka hubungan kedua variabel tersebut dikatakan bersifat searah. Bermakna bahwa apabila umur meningkat maka motivasi petani juga akan meningkat.

Berdasarkan Tabel 4 diatas, dapat diketahui bahwa terdapat hubungan yang tidak siginifikan antara umur dengan motivasi petani cengkeh. Hal ini dapat dilihat dari nilai sig, (2tailed) sebesar 0,355, artinya lebih besar dari alpha 0,05 Hubungan yang tidak signifikan ini terjadi karena petani yang berumur baik tua ataupun muda sama-sama memiliki motivasi untuk tetap membudidayakan tanaman cengkeh.Tanaman cengkeh juga mudah untuk diusahakan, sehingga bisa diusahakan oleh siapa saja baik petani yang berumur tua atau muda.

Petani tetap membudidayakan tanaman cengkeh dan mempunyai motivasi yang tinggi untuk membudidayakannya.Terbukti dengan harga tanaman cengkeh yang jatuh dan cendrung fluktuatif tidak menyurutkan motivasi mereka untuk menanam cengkeh. Petani yang berumur muda atau tua sama-sama membuka kesempatan untuk bekerjasama dengan orang lain dalam budidaya tanaman cengkeh. Kerjasama tersebut bisa terjalin antar petani, petani dengan pedagang, petani dengan penyuluh, atau kerjasama dengan yang lainnya. Dapat disimpulkan bahwa umur tidak mempengaruhi motivasi petani dalam membudidayakan tanaman cengkeh namun berhubungan searah antar variabel.

\section{Hubungan antara pendidikan dengan motivasi petani cengkeh}

Tingkat kekuatan (keeratan) hubungan antar variabel pendidikan dan motivasi petani berdasarkan tabel di atas maka dapat kita peroleh nilai koefisien korelasi sebesar 0,088. Bermakna untuk tingkat kekuatan hubungan antar variabelnya pendidikan dengan motivasi petani dikatergorikan sangat lemah. Melihat arah (jenis) hubungan antar variabel pendidikan dengan motivasi petani pada angka koefisien korelasi pada tabel bernilai positif yaitu $(0,088)$, maka hubungan kedua variabel tersebut dikatakan bersifat searah. Bermakna bahwa apabila pendidikan meningkat maka motivasi petani juga akan meningkat.

Berdasarkan Tabel 18 diatas, dapat dilihat bahwa terdapat hubungan yang tidak siginifikan antara Pendidikan dengan motivasi petani cengkeh. Hal ini dapat dilihat dari nilai sig, (2-tailed) sebesar 0,544, artinya lebih besar dari alpha 0,05 Hubungan yang tidak signifikan ini terjadi karena motivasi dalam budidaya tanaman cengkeh ini tidak diperoleh dari pendidikan formal. yang ditempuh oleh responden. Berpendidikan tinggi ataupun rendah, seseorang yang telah memutuskan sebagai petani cengkeh akan melakukan budidaya sesuai dengan keinginannya.

Petani akan tetap melakukan budidaya tanaman cengkeh tanpa memperhatikan pendidikan yang dimiliki. Mereka melakukan budidaya sesuai dengan keinginannya masingmasing dengan berbagai pertimbangan yang mereka miliki. Mereka memilih tanaman cengkeh untuk dibudidayakan meskipun harga sedang turun, tetapi mereka juga membudidayakan tanaman lain untuk lebih memenuhi kebutuhan hidupnya. Dapat disimpulkan bahwa pendidikan tidak mempengaruhi motivasi petani dalam membudidayakan tanaman cengkeh dan berhubungan searah antar variabel dengan hubungan keeratan sangat lemah. 


\section{Hubungan antara Luas Lahan dengan motivasi petani cengkeh}

Tingkat kekuatan (keeratan) hubungan antar variabel luas lahan dan motivasi petani berdasarkan tabel output di atas maka dapat kita peroleh nilai koefisien korelasi sebesar ,438**. Bermakna untuk tingkat kekuatan hubungan antar variabelnya umur dengan motivasi petani dikatergorikan cukup.

Melihat arah (jenis) hubungan antar variabel luas lahan dengan motivasi petani pada angka koefisien korelasi pada tabel bernilai positif yaitu $\left(0,438^{* *}\right)$ maka hubungan kedua variabel tersebut dikatakan bersifat searah. Bermakna bahwa apabila luas lahan meningkat maka motivasi petani juga akan meningkat.

Berdasarkan Tabel 18 diatas, dapat dilihat bahwa terdapat hubungan yang sangat siginifikan antara Pendidikan dengan motivasi petani cengkeh. Hal ini dapat dilihat dari nilai sig, (2-tailed) sebesar 0,001, artinya lebih kecil dari alpha 0,05. Berdasarkan analisis tersebut dapat diketahui keragaman luas penguasaan lahan yang dimiliki oleh petani sangat berpengaruh pada motivasi petani dalam budidaya tanaman cengkeh. Hal tersebut disebabkan petani yang memiliki lahan lebih luas lebih produktif baik dari segi pendapatan dan produksinya dalam menghasilkan cengkeh dibandingkan dengan lahan yang sempit.

Luas penguasaan lahan merupakan salah satu faktor utama yang akan mempengaruhi jumlah produksi dari budidaya yang dilakukan petani.Bagaimanapun petani yang memiliki lahan luas dan sempit tetap bisa melakukan budidaya tanaman cengkeh, karena tanaman cengkeh bisa diusahakan dalam lahan yang luas atau sempit.

Dapat disimpulkan bahwa luas lahansangat mempengaruhi motivasi petani dalam membudidayakan tanaman cengkeh dan berhubungan searah antar variabel dengan hubungan keeratan cukup.

\section{Hubungan antara Pendapatan dengan motivasi petani cengkeh}

Tingkat kekuatan (keeratan) hubungan antar variabel pendapatan dan motivasi petani berdasarkan tabel output di atas maka dapat kita peroleh nilai koefisien korelasi sebesar , $471^{* *}$. Bermakna untuk tingkat kekuatan hubungan antar variabelnya umur dengan motivasi petani dikatergorikan cukup.

Melihat arah (jenis) hubungan antar variabel pendapatan dengan motivasi petani pada angka koefisien korelasi pada tabel bernilai positif yaitu $\left(0,471^{* *}\right)$ maka hubungan kedua variabel tersebut dikatakan bersifat searah. Bermakna bahwa apabila pendapatan meningkat maka motivasi petani juga akan meningkat.

Berdasarkan Tabel 18 diatas, dapat dilihat bahwa terdapat hubungan yang sangat siginifikan antara pendapatan dengan motivasi petani cengkeh. Hal ini dapat dilihat dari nilai sig, (2-tailed) sebesar 0,001, artinya lebih kecil dari alpha 0,05. Berdasarkan analisis tersebut dapat diketahui bahwa pendapatan sangat mempengaruhi motivasi petani dalam budidaya tanaman cengkeh. Hal ini disebabkan petani yang berpendapatan tinggi lebih memiliki hasrat hasrat dan motivasi untuk memperluas lahannya agar semakin meningkat produktivitasnya dengan harapan semakin tinggi lagi penghasilan yang diperoleh, maka kebutuhan dan keinginan dapat terpenuhi. Tanaman cengkeh membutuhkan modal yang cukup besar dalam memperluas dan membudidayakannya sehingga dibuthkan biaya tambahan yang ekstra.

Budidaya tanaman cengkeh tetap dilakukan baik dengan petani pendapatan tinggi dan petani pendapatan rendah agar dapat memenuhi kebutuhan ekonomi serta memperoleh dampak positif secara sosial yaitu dapat mempererat persaudaraan antar petani sehingga terjalin kerjasama yang baik dalam kelompok tani dan masyarakat. Dapat disimpulkan bahwa pendapatan sangat mempengaruhi motivasi petani dalam membudidayakan tanaman cengkeh dan berhubungan searah antar variabel dengan hubungan keeratan cukup. 


\section{Hubungan Motivasi Petani dengan Faktor Pendorong Petani dalam Budidaya Tanaman Cengkeh}

Analisis hubungan antara faktor pendorong yang meliputi lingkungan ekonomi, dan keuntungan budidaya tanaman cengkeh dengan motivasi petani sangat penting diketahui untuk melihat sejauh mana hubungan antara variabel-variabel tersebut saling mempengaruhi. Untuk mengetahui hubungan antara umur, pendidikan, luas lahan dan pendapatan dengan motivasi petani digunakan analisis korelasi Rank Spearman's dengan bantuan perangkat IBM SPSS (Statistical Package for Social Sciences) 24 .

Tabel 5 . Nilai Signifikan dan Koefiensi Korelasi Rank Spearman's Hubungan antara lingkungan ekonomi, dan keuntungan budidaya tanaman cengkeh dengan motivasi petani

\begin{tabular}{|c|c|c|c|c|}
\hline \multirow[t]{2}{*}{ Faktor Pendorong } & \multicolumn{4}{|c|}{ Motivasi Petani } \\
\hline & Sig. (2 tailed) & Kriteria & $\begin{array}{c}\text { Correlation } \\
\text { Coef. }\end{array}$ & Kriteria \\
\hline $\begin{array}{l}\text { Lingkungan } \\
\text { Ekonomi }\end{array}$ & 0,003 & Signifikan & $0,414^{* *}$ & Cukup \\
\hline $\begin{array}{l}\text { Keuntungan } \\
\text { Budidaya Tanaman } \\
\text { cengkeh }\end{array}$ & 0,187 & Tidak sig. & 0,190 & Sangat lemah \\
\hline $\begin{array}{l}\text { Faktor Pendorong } \\
\text { (total) }\end{array}$ & 0,007 & Signifikan & $0,380^{* *}$ & Cukup \\
\hline
\end{tabular}

Sumber: Data Primer(Diolah), $2017 \quad$ Keterangan: **) Berhubungan sangat nyata pada $\alpha=0,05$

\section{Hubungan antara lingkungan ekonomi dengan motivasi petani cengkeh}

Tingkat kekuatan (keeratan) hubungan antar variabel lingkungan ekonomi dan motivasi petani berdasarkan tabel output di atas maka dapat kita peroleh nilai koefisien korelasi sebesar , $414^{* *}$. Bermakna untuk tingkat kekuatan hubungan antar variabelnya lingkungan ekonomi dengan motivasi petani dikatergorikan cukup.

Melihat arah (jenis) hubungan antar variabel lingkungan ekonomi dengan motivasi petani pada angka koefisien korelasi pada tabel bernilai positif yaitu $\left(0,414^{* *}\right)$ maka hubungan kedua variabel tersebut dikatakan bersifat searah. Bermakna bahwa apabila lingkungan ekonomi meningkat maka motivasi petani juga akan meningkat.

Berdasarkan Tabel 19 diatas, dapat dilihat bahwa terdapat hubungan yang sangat siginifikan antara lingkungan ekonomi dengan motivasi petani cengkeh. Hal ini dapat dilihat dari nilai sig, (2-tailed) sebesar 0,003, artinya lebih kecil dari alpha 0,05. Berdasarkan analisis tersebut dapat diketahui bahwa lingkungan ekonomi sangat mempengaruhi motivasi petani dalam budidaya tanaman cengkeh. Variabel yang dinilai dalam lingkungan ekonomi antara lain ketersediaan sarana produksi dan adanya jaminan pasar. Hubungan signifikan ini terjadi karena adanya ketersediaan sarana produksi yang memudahkan petani cengkeh memperoleh bibit dan pupuk, yang mereka butuhkan. Kemudahan yang diperoleh petani tersebut akan memberikan motivasi kepada petani untuk melakukan budidaya tanaman cengkeh.Semakin tinggi ketersediaan sarana produksi maka motivasi petani akan semakin tinggi. Hal ini karena ketersediaan sarana produksi memberikan pengaruh yang besar terhadap motivasi petani dalam membudidayakan tanaman cengkeh.

Kemudian Adanya jaminan pasar yang mendukung akan mempengaruhi motivasi petani. Pemasaran cengkeh memang ada perjanjian antara pedagang dengan petani, tetapi hanya 
sebatas membeli saja. Semisal tidak ada pedagang cengkeh di desa mereka atau tidak ada pedagang pengumpul maka cengkeh tidak bisa dipasarkan. Hal ini menyebabkan petani sangat tergantung pada pedagang. Dapat disimpulkan bahwa lingkungan ekonomi sangat mempengaruhi motivasi petani dalam budidaya tanaman cengkeh dan berhubungan searah antar variabel dengan hubungan keeratan cukup.

\section{Hubungan antara keuntungan budidaya tanaman cengkeh dengan motivasi petani cengkeh}

Tingkat kekuatan (keeratan) hubungan antar keuntungan budidaya tanaman cengkeh dan motivasi petani berdasarkan tabel output di atas maka dapat kita peroleh nilai koefisien korelasi sebesar 0,190. Bermakna untuk tingkat kekuatan hubungan antar variabelnya dikatergorikan sangat lemah.

Melihat arah (jenis) hubungan antar variabel keuntungan budidaya tanaman cengkeh dengan motivasi petani pada angka koefisien korelasi pada tabel bernilai positif yaitu $(0,190)$, maka hubungan kedua variabel tersebut dikatakan bersifat searah. Bermakna bahwa apabila keuntungan budidaya meningkat maka motivasi petani juga akan meningkat.

Berdasarkan Tabel 19 diatas, dapat dilihat bahwa terdapat hubungan yang tidak siginifikan antara keuntungan budidaya cengkeh dengan motivasi petani cengkeh. Hal ini dapat dilihat dari nilai sig, (2-tailed) sebesar 0,187, artinya lebih besar dari alpha 0,05. Variabelvariabel yang diuji dalam hal ini adalah tingkat potensi kesuburan lahan dan tingkat kesesuian budaya setempat. Hubungan yang tidak signifikan ini terjadi karena walaupun potensi lahan tanaman cengkeh sangat sesuai dan subur tanpa harus dipupuk pun akan tetapi karena jarak dan medannya lahan cengkeh di daerah perbukitan, hal ini menjadi kendala bagi setiap petani untuk merawatnya terlebih lagi saat membuka lahan baru, memerlukan energy dan modal yang ekstra.

Tanaman cengkeh memang telah dikenal sangat lama dan dibudidayakan dari turuntemurun oleh petani, tetapi hal ini tidak mempengaruhi motivasi petani untuk menanamnya. Banyak hal lain yang menjadi alasan petani memilih tanaman cengkeh untuk dibudidayakan. Kesesuaian tanaman cengkeh dengan budaya setempat ini jika disertai dengan adanya kerjasama yang baik antara pedagang dan petani maka pemasaran akan lebih baik, karena kerjasama merupakan salah satu budaya masyarakat yang melekat dalam diri setiap individu yang hidup bermasyarakat. Dapat disimpulkan bahwa keuntungan budidaya tanaman cengkeh tidak mempengaruhi motivasi petani dalam membudidayakan tanaman cengkeh dan berhubungan searah antar variabel dengan hubungan keeratan sangat lemah.

\section{Hubungan Motivasi Petani dengan Faktor Penghambat Petani dalam Budidaya Tanaman Cengkeh}

Analisis hubungan antara faktor penghambat yang meliputi modal, hama dan penyakit, serta ketidaktersediannya kredit usaha tani dengan motivasi petani sangat penting diketahui untuk melihat sejauh mana hubungan antara variabel-variabel tersebut saling mempengaruhi. Untuk mengetahui hubungan antara modal, hama dan penyakit, serta ketidaktersediannya kredit usaha tani dengan motivasi petani digunakan analisis korelasi Rank Spearman's dengan bantuan perangkat IBM SPSS (Statistical Package for Social Sciences) 24 . 
Tabel 6. Nilai Signifikan dan Koefiensi Korelasi Rank Spearman's Hubungan antara Minimnya Modal, Ketidaktersediannya Kredit Usaha Tani, dan Hama Penyakit dengan motivasi petani

\begin{tabular}{lcccc}
\hline Faktor Penghambat & \multicolumn{4}{c}{ Motivasi Petani } \\
\cline { 2 - 5 } & Sig. (2 tailed) & Kriteria & $\begin{array}{c}\text { Correlation } \\
\text { Coef. }\end{array}$ & Kriteria \\
\hline Minimnya Modal & 0,024 & Signifikan &,$- 319^{*}$ & Cukup \\
Ketidaktersediannya & 0,973 & Tidak sig. & $-0,005$ & Sangat lemah \\
Kredit Usaha Tani & & & & Cukup \\
Hama dan Penyakit & 0,065 & Tidak sig. & 0,263 & Sangat lemah \\
Faktor Penghambat & 0,970 & Tidak sig. & 0,005 & San \\
\hline
\end{tabular}

Sumber : Data Primer (Diolah), 2017 Keterangan: *) Berhubungan nyata pada $\alpha=$ 0,05

\section{Hubungan antara modal tanaman cengkeh dengan motivasi petani cengkeh}

Tingkat kekuatan (keeratan) hubungan antar variabel modal dan motivasi petani berdasarkan tabel output di atas maka dapat kita peroleh nilai koefisien korelasi sebesar , , $319^{*}$.Bermakna untuk tingkat kekuatan hubungan antar variabelnya modal dengan motivasi petani dikatergorikan cukup. .

Melihat arah (jenis) hubungan antar variabel modal dengan motivasi petani pada angka koefisien korelasi pada tabel bernilai negatif yaitu $\left(-, 319^{*}\right)$.maka hubungan kedua variabel tersebut dikatakan bersifat tidak searah. Bermakna bahwa apabila modal meningkat maka motivasi petani tidak akan akan meningkat dan sebaliknya.

Berdasarkan Tabel 20 diatas, dapat dilihat bahwa terdapat hubungan yang siginifikan antara modal dengan motivasi petani cengkeh. Hal ini dapat dilihat dari nilai sig, (2-tailed) sebesar 0,024, artinya lebih kecil dari alpha 0,05. Hubungan signifikan dengan keeratan cukup namun tidak searah ini terjadi karena dengan keterbatasannya modal tidak akan menghambat petani atau pun menjadi motivasi petani untuk meningkatkan budidaya tanaman cengkehnya. Namun apabila dengan adanya modal yang baik maka baik pula motivasi petani dalam budidaya tanaman cengkeh. Dapat disimpulkan bahwa keterbatasan modal mempengaruhi motivasi petani dalam membudidayakan tanaman cengkeh dan berhubungan tidak searah antar variabel dengan hubungan keeratan cukup.

\section{Hubungan antara Ketidaktersediannya Kredit Usaha Tani tanaman motivasi petani cengkeh}

cengkeh dengan

Tingkat kekuatan (keeratan) hubungan antar variabel Ketidaktersediannya Kredit Usaha Tani dan motivasi petani berdasarkan tabel output di atas maka dapat kita peroleh nilai koefisien korelasi sebesar , 0,005. Bermakna untuk tingkat kekuatan hubungan antar variabelnya Ketidaktersediannya Kredit Usaha Tani dengan motivasi petani dikatergorikan sangat lemah.

Melihat arah (jenis) hubungan antar variabel Ketidaktersediannya Kredit Usaha Tani dengan motivasi petani pada angka koefisien korelasi pada tabel bernilai negatif yaitu $(-0,005)$ maka hubungan kedua variabel tersebut dikatakan bersifat tidak searah. Bermakna bahwa apabila Ketidaktersediannya Kredit Usaha Tani meningkat maka motivasi petani tidak akan akan meningkat dan sebaliknya. 
Berdasarkan Tabel 20 diatas, dapat dilihat bahwa terdapat hubungan yang tidak siginifikan antara ketidaktersediannya kredit usaha tani dengan motivasi petani cengkeh. Hal ini dapat dilihat dari nilai sig, (2-tailed) sebesar 0,973, artinya lebih besar dari alpha 0,05. Hubungan yang tidak signifikan ini terjadi karena ketidaktersediaan kredit usahatani ini tidak menjadi hambatan baik oleh petani maupun oleh semua anggota kelompok tani dalam budidaya tanaman cengkeh, sehingga ketidaktersediaan kredit tidak berpengaruh pada motivasi petani dalam membudidayakan tanaman cengkeh.

Adanya Kredit Usaha Tani sebenarnya cukup membantu dalam hal biaya pengolahan tanaman cengkeh, akan tetapi tidak semua petani bisa memanfaatkannya dengna baik. Ada tidaknya ketersediaan kredit yang mendukung atau tidak mendukung, petani akan tetap melakukan budidaya tanaman cengkeh untuk memenuhi kebutuhan ekonomi dan sosialnya. Dapat disimpulkan bahwa ketidaktersediannya kredit usaha tani tidak mempengaruhi motivasi petani dalam membudidayakan tanaman cengkeh dan berhubungan tidak searah antar variabel dengan hubungan keeratan sangat lemah.

\section{Hubungan antara Hama dan Penyakit tanaman cengkeh dengan motivasi petani cengkeh}

Tingkat kekuatan (keeratan) hubungan antar variabel hama dan penyakitdan motivasi petani berdasarkan tabel output di atas maka dapat kita peroleh nilai koefisien korelasi sebesar 0,263 . Bermakna untuk tingkat kekuatan hubungan antar variabelnya hama dan penyakitdengan motivasi petani dikatergorikan cukup.

Melihat arah (jenis) hubungan antar variabel hama dan penyakit dengan motivasi petani pada angka koefisien korelasi pada tabel bernilai positif yaitu $(0,263)$ maka hubungan kedua variabel tersebut dikatakan bersifat searah. Bermakna bahwa apabila hama dan penyakitmeningkat maka motivasi petani akan akan meningkat.

Berdasarkan Tabel 20 diatas, dapat dilihat bahwa terdapat hubungan yang tidak siginifikan antara hama dan penyakit dengan motivasi petani cengkeh. Hal ini dapat dilihat dari nilai sig, (2-tailed) sebesar 0,065, artinya lebih besar dari alpha 0,05. Hubungan yang tidak signifikan ini terjadi karena hama dan penyakit tidak menjadi hambatan dan persoalan bagi petani cengkeh, karena baik dari segi tanaman/bibit cengkeh yang relative tahan serangan dan penyakit dengan didukung lahan perbukitan yang tinggi dan tingkat kesuburannya sangat baik, mendukung petani untuk tetap membudidayakan tanaman cengkeh. Dapat disimpulkan bahwa hama dan penyakit tidak mempengaruhi motivasi petani dalam membudidayakan tanaman cengkeh dan berhubungan searah antar variabel dengan hubungan keeratan cukup.

\section{Kesimpulan}

\section{KESIMPULAN DAN SARAN}

Adapun kesimpulan dalam penilitian ini adalah;

1. Tingkat motivasi petani budidaya tanaman cengkeh berada dalam kategori tinggi, yaitu motivasi ekonomi dan sosiologis, dalam motivasi ekonomi dimana petani menanam tanaman cengkeh dengan harapan dapat memenuhi kebutuhan ekonominya. Sedangkan motivasi sosiologisnya juga termasuk dalam kategori tinggi, dimana beranggapan bahwa menanam tanaman cengkeh dapat membawa dampak positif secara social budaya.

2. Terdapat hubungan signifikan antara faktor pendorong dengan motivasi petani yakni dengan nilai signifikan 0,01 berhubungan searah antara motivasi dan tingkat keeratan hubungan korelasi yang cukup, sebesar 0,380, sehingga apabila terdapat kecendrungan factor pendorong ditingkatkan maka motivasi petani pun akan terus meningkat. Variabel yang signifikan dalam 
faktor pendorong adalah lingkungan ekonomi sebesar $(0,414)$ dan variabel keuntungan budidaya tanaman cengkeh tidak signifikan dan terdapat hubungan yang sangat signifikan juga antara status sosial ekonomi dengan motivasi petani yakni dengan nilai signifikan 0,01 berhubungan searah antara motivasi dan tingkat keeratan hubungan korelasi yang cukup, sebesar 0,401, sehingga apabila terdapat kecendrungan status sosial petani ditingkatkan maka motivasi petani pun akan terus meningkat, dilihat dari tingkat signifikan dan tingkat keeratan hubungan dalam variable status sosial petani dari tinggi ke rendah adalah; Pendapatan $(0,471)$, Luas lahan $(0,438)$ dan tidak terdapat signifikan antara umur dan pendidikan terhadap motivasi. 3. Tidak terdapat hubungan yang signifikan antara faktor penghambat dengan motivasi petani cengkeh, yakni dengan nilai $0,97>\alpha$, variabel yang tidak signifikan didalamnya antara lain; hama dan penyakit dan ketidaktersediannya kredit usaha tani. Namun terdapat satu variabel yang signifkan yakni minimnya modal dengan nilai signifikan 0,05 berhubungan tidak searah antara motivasi dan tingkat keeratan hubungan korelasi yang cukup, sebesar 0,319, sehingga apabila terdapat kecendrungan minimnya modal petani semakin rendah maka motivasi petani tidak akan berpengaruh.

\section{Saran}

Adapun saran dalam penilitian ini adalah;

1. Motivasi yang tinggi yang terdapat dalam budidaya tanaman cengkeh menunjukkan bahwa petani cengkeh masih ingin terus membudidayakan tanaman cengkeh, untuk itu diharapkan pemerintah turut membantu menyelesaikan masalah pemasaran melalui kerjasama dari pemerintah dengan mempromosikan Kecamatan Lhoknga sebagai penghasil cengkeh yang produktif sehingga dapat memperluas area pemasaran.

2. Melihat adanya hubungan yang signifikan antara tingkat motivasi petani dengan lingkungan ekonomi petani dan status sosial ekonomi petani, sebaiknya pemerintah lebih aktif mengambil andil dalam pelaksanaan penyuluhan terhadap petani cengkeh serta peningkatan sarana prasarana produksi dan jaminan pasar yang sangat berpengaruh bagi aspek motivasi petani dalam peningkatan produksinya.

3. Melihat modal merupakan factor yang berpengaruh bagi tingkat motivasi petani dengan factor-faktor penghambat motivasi petani, maka diharapkan pemerintah dapat memberikan support dan perhatian lebih terhadap petani dalam memberikan bantuan modal lebih agar petani cengkeh dapat mengembangkan usaha taninya kearah yang lebih baik.

\section{DAFTAR PUSTAKA}

Ahmadi, A, 2002, Psikologi Sosial, Edisi Revisi, Penerbit Rineka Cipta. Jakarta..

Adiwilaga, Anwas. 1992. Ilmu Usaha Tani: Cetakan II. Bandung: Alumni.

Arifin, Zainal. 2014. Penelitian Pendidikan. Bandung : PT Remaja Rosdakarya.

Clegg, B. 2001. Instan Motivator: 79 Cara Instan Menumbuhkan Motivasi. Erlangga. Jakarta.

Deny, R. 1997. Sukses Memotivasi Jurus Jitu Meningkatkan Prestasi. PT Gramedia Pustaka Utama. Jakarta. 
Effendy, O. U. 1983. Human Relation dan Public Relation Dalam Manjemen. Alumni. Bandung.

Hadisapoetro, S. 1973. Pembangunan Pertanian. Departemen Ekonomi Pertanian Fakultas Pertanian UGM. Yogyakarta.

Handoko, M., 1992. Motivasi Daya Penggerak Tingkah Laku. Kanisius. Yogyakarta.

Kilvington, M., Allen, W. dan Kravchenko, C. (1999). Improving Farmer Motivation Within Tb Vector Control. Landcare Research Contract Report.

Lailida, Junan Amsta., 2014. Motivasi Petani Dan Strategi Pengembangan Usahatani Kopi Arabika Rakyat Di Kecamatan Sumber Wringin Kabupaten Bondowoso.Skripsi.Jurusan Sosial Ekonomi Pertanian Fakultas Pertanian Universitas Negeri Jember.

Moekijat. 1981. Motivasi dan Pengembangan Manajemen. Alumni. Bandung. 1990. Asas-asas Perilaku Organisasi. Mandar Maju. Bandung.

Nurdjannah, N., 2004, Diversifikasi Penggunaan Cengkeh, Persektif. Vol 3. No. 2, 61- 70

Riduwan. 2009. Dasar-Dasar Statistika. Bandung. Alfabeta.

Robert, R. 1985. Masyarakat Petani dan Kebudayaan. CV Rajawali. Jakarta.

Rogers, E. M. 1985. Komunikasi Pembangunan. LP3ES. Jakarta.

Thomas, A.N.S. 2007. Tanaman Obat Tradisional. Yogyakarta.Kanisus.

Wicaksono, A. 2005. Motivasi Petani Dalam Pengembangan Budidaya Panili (Vanilla planifolia, Andrews) (Kasus Pengenalan Panili di Kabupaten Klaten). Fakultas Pertanian Universitas Sebelas Maret. Surakarta.

Winardi. 2004. Motivasi dan Pemotivasian Dalam Manajemen. Jakarta.PT Raja Grafindo.

Wirartha, I. M. 2006. Metodologi Penetilian Sosial Ekonomi. Yogyakarta: C.V Andi Offset. 